\title{
Characteristics, Importance and Objectives of Research: An Overview of the Indispensable of Ethical Research
}

\author{
Md. Sirajul Islam ${ }^{1}$, Sofiah Samsudin ${ }^{2}$ \\ * PhD candidate, Department of Qur'an \& Sunnah Studies, Kulliyyah of Islamic Revealed Knowledge and Human Sciences, International Islamic \\ University Malaysia, 53100 Jalan Gombak, Kuala Lumpur, Malaysia \\ ** Department of Qur'an \& Sunnah Studies, Kulliyyah of Islamic Revealed Knowledge and Human Science, International Islamic University \\ Malaysia, 53100 Jalan Gombak, Selangor, Kuala Lumpur, Malaysia. \\ DOI: 10.29322/IJSRP.10.05.2020.p10138 \\ http://dx.doi.org/10.29322/IJSRP.10.05.2020.p10138
}

\begin{abstract}
This study focuses on Characteristics, Importance and Objectives (CIO) of research. The main aim of this article is to emphasize on research ethics. Knowledge in characteristics, importance and objectives of research motivate to be ethical in research. It is the utmost importance knowing these three basic subjects of research for researchers specially for novice researchers. These improve research mentality, academic attitude and way of thinking that enable researcher to choose research area, generate constructive potential research title. In addition, motivate to know what the problem is and cause of problem and how to solve the recognized valid problem. In fact, an outstanding unique contribution of a research depends on applying research ethics. A profound understanding the (CIO) of research reinforce research motive and enable to follow research ethics that is core requirement in each research activities.
\end{abstract}

Index Terms- characteristics of research, importance of research, objectives of research, research problem, research ethics, basic research, applied research.

\section{INTRODUCTION}

$\mathrm{R}$ esearch is primarily an enterprise of knowledge construction. The researcher (and co-researchers), with his or her participants, is engaged in producing knowledge ${ }^{1}$. Studying meanings and definitions of research help to understand basic concept of research. Also, we can know the basic idea of characteristics, importance and objectives of research by studying

\footnotetext{
${ }^{1}$ Guillemin, M., \& Gillam, L. (2004). Ethics, reflexivity, and "ethically important moments" in research. Qualitative inquiry, 10(2), 261-280.

${ }^{2}$ Blume, S., \& Hiddinga, A. (2010). Disability studies as an academic field. Med. Anthropol, 22(2), 225-36.

${ }^{3}$ Blaikie, N., \& Priest, J. (2017). Social research: Paradigms in action. John Wiley \& Sons.

${ }^{4}$ Galas, D. J., Patrinos, A., \& DeLisi, C. (2017). Notes from a Revolution Lessons from the Human Genome Project. Issues in Science and Technology, 33(3), 57-62.

${ }^{5}$ Iyama, S. (2004). The USPTO's proposal of a biological research tool patent pool doesn't hold water. Stan. L. Rev., 57, 1223.
}

its meanings and definitions. Nevertheless, it is essential for researchers understanding the particularly characteristics, importance and objectives of research in the light of reliable scholars' opinion. These motivate a researcher to be a skilful and an ethical researcher by following relevant research methodology and research ethics as though they do not ignore CIO of research which lead researcher to find appropriate answer of research questions that is expected objectives of each research forever. Usually, any type of research cannot be conducted without some basic characteristics of research. Nevertheless, few characteristics of research are depends on type, area and subject of research. For example, characteristics of disability research ${ }^{2}$, characteristics of social research ${ }^{3}$, characteristics of biological research ${ }^{4},{ }^{5}$, Each research has a particular importance ${ }^{6}$ and objective ${ }^{7}$. On the one hand, objectiveless research is a vain effort; on the other hand, evil objective of a research is unethical effort. An ethical and skilful researcher is very conscious about valid and permissible objective of research.

\section{INDISPENSABLE OF ETHICAL RESEARCH}

Ethics is a branch of philosophy that deals with morals. It is the philosophy of what is right and wrong ${ }^{8}$. Ethics is a branch of philosophy that theoretically, logically, and rationally determines right from wrong, good from bad, moral from immoral, and just from unjust actions, conducts, and behavior ${ }^{9}$. The motive force in Islamic ethics is the notion that every human being is called to

${ }^{6}$ Arnold, C., \& Voigt, K. I. (2017). Ecosystem Effects of the Industrial Internet of Things on Manufacturing Companies. Acta Infologica, 1(2), 99-108.

${ }^{7}$ Guil, J. M., Masiá, A. P., Paniego, A. R., \& Menayo, J. T. (1998). Energetics of $\mathrm{H} 2$ and $\mathrm{O} 2$ adsorption on $\mathrm{Ir} / \gamma$-A12O3 and $\mathrm{Ir} / \mathrm{SiO} 2$ catalysts. Dependence on support and on metal particle size. Thermochimica acta, 312(1-2), 115-124.

${ }^{8}$ Shamoo, A. E., \& Dunigani, C. D. (2000). Ethics in Research2 (44535B). Proceedings of the Society for Experimental Biology and Medicine, 224(4), 205-210.

${ }^{9}$ Mujtaba, B. G. (1997, March). Corporate Ethics Training Programs. In Developments in Business Simulation and Experiential Learning: Proceedings of the Annual ABSEL conference (Vol. 24). 
"command the good and forbid the evil ${ }^{10 "}$ (Qur'an 9:112, 22:41, 3:104) in all spheres of life (Qur'an 3:110) ${ }^{11}$.

Research ethics provides guidelines for the responsible conduct of research to ensure all research is conducted at a high ethical standard $^{12}$. It educates and monitors as well as enables responsible scientists to confirm a high ethical standard in conducting research ${ }^{13}$. It is worthwhile mentioning that the research ethics is a key part of advanced academic learning in all academic disciplines, as it prevents different forms of misconduct and fraud $^{14}$. Therefore, scientists have become increasingly aware of the importance of ethics in research and have contributed a great lot towards ethics discourse ${ }^{15}$.

There are at least two major dimensions of ethics in all research. These are (a) procedural ethics, which usually involves seeking approval from a relevant ethics committee to undertake research involving humans; and (b) "ethics in practice" or the everyday ethical issues that arise in the doing of research. It could be argued that there is another dimension-research ethics as articulated in professional codes of ethics or conduct. Most professions and organizations have professional codes of conduct (Bulmer, 1982; ${ }^{16}$ Coady \& Bloch, 1996; ${ }^{17}$ Homan, 1991) ${ }^{18}$.

In fact, truth and trustworthy results are 'flesh and bones' of scientific research. To have trustworthy results and to avoid misconduct, researchers should use optimal study designs and follow ethical standards ${ }^{19}$. In the fight against intellectual dishonesty on ethics education in science has a significant place. A general understanding of ethics in scientific research work in all its stages had to be acquired during the undergraduate course ${ }^{20}$. Definitely, the main motivation of research ethics is CIO; it is a basis of all other structures, frameworks and ethical paradigm of research. Hence, profound understanding CIO of research is vital subject for all researchers.

${ }^{10}$ Ismail, A. M., Mujani, W. K., Hussain, W. M. H. W., \& Ya'akub, N. I. (2012). The missing of moral entity in modern civilization: values and social aspects. Advances in Natural and Applied Sciences, 6(6), 985-995.

${ }^{11}$ Khan, A. A. (2012). Islamic Society: Ethics, Human Rights, Adornments \& Recreation. Defence Journal, 15(10), B1. 12 McKellar, K., \& Toth, N. (2016). Ethical Considerations in Face-to-Face and Internet-Mediated Research with Teenage Populations. In Perspectives on HCI Research with Teenagers (pp. 29-59). Springer, Cham.

${ }^{13}$ Kiulah, B. M. (2013). A Discussion On The Ethical Issues Encountered In The Process Of Carrying Out Research.

${ }^{14}$ Kruk, J. (2013). Good scientific practice and ethical principles in scientific research and higher education. Central European Journal of Sport Sciences and Medicine, 1(1), 2529.

${ }^{15}$ Master, Z. (2011). The responsible conduct of bioethics research. Accountability in Research, 18(2), 102-119.

${ }^{16}$ Bulmer, M. (Ed.). (1982). Social research ethics. London: Macmillan.

${ }^{17}$ Coady, M., \& Bloch, S. (Eds.). (1996). Codes of ethics and the professions. Melbourne, Australia: Melbourne University Press.

${ }^{18}$ Guillemin, M., \& Gillam, L. (2004). Ethics, reflexivity, and "ethically important moments" in research. Qualitative inquiry, 10(2), 261-280.

\section{CHARACTERISTICS OF RESEARCH}

Commonly researcher has to adopt few essential characters to be a good researcher. By applying these characters research work will be progressed with systematically. I have mentioned some fundamental characteristics of research. Each researcher has to be attentive on these following characteristics:

Uses Scientific Methods: Research uses scientific methods to discover facts and tries to give solutions to specified problems. Researchers follow organised procedure to carry out research. To receive better results, scientific method is used for carrying out investigation ${ }^{21}$.

Continuous Process: It is a continuous process as it studies existing facts and also develops new facts. Research also tries to distinguish relationship among variables ${ }^{22}$.

Multipurpose Activity: Research is a multipurpose activity as it not only includes collection of data but also includes predicting future, establishing relationship between variables, finding solutions to problems, and developing new theories, tools, and concepts ${ }^{23}$.

Maintains Objectivity and Eliminates Impartiality: Research is based on suitable procedures. It collects appropriate, precise and objective data to understand research problem. After data collection, researcher process data, analyse it and arrive at appropriate solutions ${ }^{24}$.

Empirical Nature: Empirical research can be undertaken to study situations where methods such as observation, experimentation or survey can be used for conducting research ${ }^{25}$. Empirical approach used to contribute towards enhancing our understanding of what the main research problems ${ }^{26}$.

Generalisation: Research conclusions can be applied to a large population. Research can be carried on sample of respondents that represents the universe where the conclusions

${ }^{19}$ Masic, I. (2012). Plagiarism in scientific publishing. Acta Informatica Medica, 20(4), 208.

${ }^{20}$ Masic, I. (2012). Plagiarism in scientific publishing. Acta Informatica Medica, 20(4), 208.

${ }^{21}$ Bhome, S. M., Prajapati, N., Deshmukh-Ghate, D., \& Ghosh, A. (2015). Research Methodology (Tools and Analysis), Himalaya Publishing House.

22Bhome, S. M., Prajapati, N., Deshmukh-Ghate, D., \& Ghosh, A. (2015). Research Methodology (Tools and Analysis),

Himalaya Publishing House.

${ }^{23}$ Bhome, S. M., Prajapati, N., Deshmukh-Ghate, D., \& Ghosh, A. (2015). Research Methodology (Tools and Analysis),

Himalaya Publishing House.

${ }^{24}$ Bhome, S. M., Prajapati, N., Deshmukh-Ghate, D., \& Ghosh, A. (2015). Research Methodology (Tools and Analysis),

Himalaya Publishing House.

${ }^{25}$ Bhome, S. M., Prajapati, N., Deshmukh-Ghate, D., \& Ghosh, A. (2015). Research Methodology (Tools and Analysis),

Himalaya Publishing House.

${ }^{26}$ Giaglis, G. M. (2008). Directions and trends in knowledge management research: Results from an empirical analysis of European projects. In Knowledge Management: Concepts, Methodologies, Tools, and Applications (pp. 1438-1449). IGI Global. 
generated through research can be applied to the complete universe $\mathrm{e}^{27}$.

Researchers Controlled Movement of the Research Procedure: In social research, there are many factors that have an effect on result. Due to various factors, some of them can be considered as controlled factors while others can be tested for possible consequences. But, it is difficult to execute controlled experiments in social researches, whereas it is easy to perform controlled experiments in pure sciences ${ }^{28}$.

Development of Concepts and Theories: Research helps to develop new concepts and theories where these innovations can be useful for the betterment of society at a large scale ${ }^{29}$. These characters are useful for all type of research. Moreover, each type of research has individual specific character.

\section{IMPORTANCE OF RESEARCH}

Research is an essential and powerful tool in leading man towards progress. Without systematic research there would have been very little progress ${ }^{30}$. Hudson Maxim ${ }^{31}$ (1853-1927) said "All progress is born of inquiry ${ }^{32}$. Doubt is often better than overconfidence, for it leads to inquiry, and inquiry leads to invention". Increased amounts of research make progress possible ${ }^{33}$. Research is significant both in scientific and nonscientific fields ${ }^{\mathbf{3 4}}$. Research is important for the following reasons: (1) A research problem refers to a complexity which a researcher or a scientific community or an industry or a government organisation or a society experiences. It may be a theoretical or a

${ }^{27}$ Bhome, S. M., Prajapati, N., Deshmukh-Ghate, D., \& Ghosh, A. (2015). Research Methodology (Tools and Analysis), Himalaya Publishing House.

${ }^{28}$ Bhome, S. M., Prajapati, N., Deshmukh-Ghate, D., \& Ghosh, A. (2015). Research Methodology (Tools and Analysis),

Himalaya Publishing House.

${ }^{29}$ Bhome, S. M., Prajapati, N., Deshmukh-Ghate, D., \& Ghosh, A. (2015). Research Methodology (Tools and Analysis),

Himalaya Publishing House.

30 Prabhat, P. and Meenu, M. P. (2015). Research

Methodology: Tools and Techniques, 1st ed, Bridge Center-

Romania.

31 Hudson Maxim (February 3, 1853 - May 6, 1927), was a

U.S. inventor and chemist who invented a variety of explosives, including smokeless gunpowder, Thomas Edison referred to him as "the most versatile man in America". 32 Bury, J. B., \& Bury, J. B. (1987). The idea of progress: An inquiry into its origin and growth. Courier Corporation.

33 Kothari, C. R. (2004). Research methodology: Methods and techniques. New Age International.

${ }^{34}$ Bhome, S. M., Prajapati, N., Deshmukh-Ghate, D., \& Ghosh, A. (2015). Research Methodology (Tools and Analysis),

Himalaya Publishing House.

35 Bhome, S. M., Prajapati, N., Deshmukh-Ghate, D., \& Ghosh, A. (2015). Research Methodology (Tools and Analysis), Himalaya Publishing House.

${ }^{36}$ Bhome, S. M., Prajapati, N., Deshmukh-Ghate, D., \& Ghosh, A. (2015). Research Methodology (Tools and Analysis), Himalaya Publishing House.

This publication is licensed under Creative Commons Attribution CC BY

http://dx.doi.org/10.29322/IJSRP.10.05.2020.p10138 practical situation. It calls for a systematic understanding and possible solution $^{35}$. (2). Research on existing theories and concepts help us recognise their range and applications ${ }^{\mathbf{3 6}}$. (3). It is the bank of knowledge and provides strategy for solving problems ${ }^{37}$. (4). It is important in industry and business for higher profits, output, and efficiency and to improve the quality of products ${ }^{38}$. (5). Mathematical and logical research on business and industry reduces the problems in them ${ }^{39}$. (6). It leads to the identification and categorisation of new materials, new living things, new stars, $\operatorname{etc}^{\mathbf{4 0}}$. (7). Inventions can be done through research ${ }^{\mathbf{4 1}}$. (8). Social research helps find answers to social problems. They explain social phenomena and try to find solution to social problems ${ }^{\mathbf{4 2}}$.

Thus, research is the fountain of knowledge for the sake of knowledge and an important source of providing guidelines for solving different business, governmental and social problems. It is a category of formal training which enables one to understand the new developments in one's field in a better way ${ }^{43}$.

\section{OBJECTIVES OF RESEARCH}

In my opinion, if we want to know objectives, type and method of research we have to focus on meaning and definitions of research. Really, there have main objectives of research in meaning and definitions of research. Nevertheless, the researcher presented distinctly objectives of research from research methodology literatures.

The purpose of research is to discover answers to questions through the application of scientific procedures. The main aim of

Also see: Bambale, A. (2014). Facilitating the PhD research process: Guides for identifying research problem and establishing research gap'. International Journal of Business, Humanities and Technology, 4(1), 116-124.

37 Bhome, S. M., Prajapati, N., Deshmukh-Ghate, D., \& Ghosh, A. (2015). Research Methodology (Tools and Analysis),

Himalaya Publishing House.

${ }^{38}$ Bhome, S. M., Prajapati, N., Deshmukh-Ghate, D., \& Ghosh, A. (2015). Research Methodology (Tools and Analysis), Himalaya Publishing House.

${ }^{9}$ Bhome, S. M., Prajapati, N., Deshmukh-Ghate, D., \& Ghosh, A. (2015). Research Methodology (Tools and Analysis), Himalaya Publishing House.

Also see: Rexford, N., \& Cunnington, P. Methodology/Dress History/Historiography.

${ }^{40}$ Bhome, S. M., Prajapati, N., Deshmukh-Ghate, D., \& Ghosh, A. (2015). Research Methodology (Tools and Analysis), Himalaya Publishing House.

${ }^{41}$ Bhome, S. M., Prajapati, N., Deshmukh-Ghate, D., \& Ghosh, A. (2015). Research Methodology (Tools and Analysis), Himalaya Publishing House.

${ }^{42}$ Bhome, S. M., Prajapati, N., Deshmukh-Ghate, D., \& Ghosh, A. (2015). Research Methodology (Tools and Analysis), Himalaya Publishing House.

${ }^{43}$ Kothari, C. R. (2004). Research methodology: Methods and techniques. New Age International. 
research is to find out the truth (information, causes, purposes, facts, knowledge, philosophy and so on) which is hidden and which has not been discovered as yet. Though each research study has its own specific purpose, we may think of research objectives might be into a number of vital objectives ${ }^{44}$. For example, (1) To portray accurately the characteristics of a particular individual, situation or a group (studies with this object in view are known as descriptive research studies) ${ }^{45}$. (2) To determine the frequency with which something occurs or with which it is associated with something else (studies with this object in view are known as diagnostic research studies $)^{46}$. (3) To test a hypothesis of a causal relationship between variables (such studies are known as hypothesis-testing research studies) ${ }^{47}$. (4) To understand clearly an observed phenomenon and explain its logic and reason for happening. (5) To get insights about problem. (6) To find solutions for a problem. (7) To test existing laws or theories. (8) To develop new ideas, concepts and theories. (9) To identify areas where research could make the difference. (10) To predict future of events $^{48}$. Additionally, (11) To interpret theory. (12) To develop research methodology from the divine perspective. (13) To interpret the divine knowledge (14) To derive philosophy, principle and solution of problem from the Holy Qur'an (15) To understand the truth and reality. (16) To know the sciences (17) To know the divine creativities in Creation. (18) To appropriate management of resources. (19) To establish human and environment friendly society. (20) To know the Creator. (21) To know the purpose of human life. (22) To know how to protect human life from astray. (23) To arrange acceptable answer of valid research questions. (24) To extend dimensions of beneficial knowledge. (25) To identify the research gap in basic research. (26) To recognize the research problem in applied research. (27) To arrest the causes of problem. (28) To examine past research works.

These objectives are a summary of meaning and definition of research. From these objectives one more or two more or three more objectives could be in a research. It is not a mandatory must be only an objective or one more objectives in a research. Research work cannot be conducted aimlessly. Hence, must be minimum an objective in a research.

\section{CONCLUSION}

We cannot confine Characteristic, Importance and Objectives (CIO) of research. These rely on type, area and topic

\footnotetext{
${ }^{44}$ Kothari, C. R. (2004). Research methodology: Methods and techniques. New Age International.

${ }^{45}$ Kothari, C. R. (2004). Research methodology: Methods and techniques. New Age International.

Also: Tyagi, N., Varshney, R. G., \& Chandramouli, A. B. (2013).

A novel approach to study the research methodology. International Journal of Management, IT and Engineering, 3(11), 248.

${ }^{46}$ Donnell, J. D. (1970). Empirical Research: A Key to the Kingdom for the Business Law Instructor. Am. Bus. LJ, 8, 287. Also: Kothari, C. R. (2004). Research methodology: Methods and techniques. New Age International.
}

of research. Fundamental CIO of research generally for all type and area of research have been presented in this article. In fact, each researcher has to know these CIO, and endeavour first of all what are academically approvals CIO of his research. Also, have to be determined on legal CIO of his research from beginning to conclusion. Should be strictly determined on that should not be moved away from research ethics by any interfering, unethical influence, political force, secularism notion as well as unethical personal interest that is anti-religious, and harmful for social and natural environment and so on. Unfortunately, few so-called researchers who give priority unethical interest on research ethics; consequently they underestimate the CIO of their research. Therefore, in this case we ethical researchers, scholars and scientists do not allow this is an acceptable research. Unethical research is poison in research resources. Apparently, such researches have been polluting the research environment as well as research world for a long period. Hence, appreciation characteristics, importance and objectives of research are keys for ethical, acceptable and fruitful research for ever.

\section{REFERENCES}

[1] Arnold, C., \& Voigt, K. I. (2017). Ecosystem Effects of the Industrial Internet of Things on Manufacturing Companies. Acta Infologica, 1(2), 99-108.

[2] Bambale, A. (2014). Facilitating the PhD research process: Guides for identifying research problem and establishing research gap'. International Journal of Business, Humanities and Technology, 4(1), 116-124.

[3] Bhome, S. M., Prajapati, N., Deshmukh-Ghate, D., \& Ghosh, A. (2015) Research Methodology (Tools and Analysis), Himalaya Publishing House.

[4] Bist, R. B. (2014). Research Procedure: An Introduction. Journal of NELTA Surkhet, 4, 34-40.

[5] Blaikie, N., \& Priest, J. (2017). Social research: Paradigms in action. John Wiley \& Sons.

[6] Blume, S., \& Hiddinga, A. (2010). Disability studies as an academic field Med. Anthropol, 22(2), 225-36.

[7] Bulmer, M. (Ed.). (1982). Social research ethics. London: Macmillan.

[8] Bury, J. B., \& Bury, J. B. (1987). The idea of progress: An inquiry into its origin and growth. Courier Corporation.

[9] Coady, M., \& Bloch, S. (Eds.). (1996). Codes of ethics and the professions. Melbourne, Australia: Melbourne University Press.

[10] Donnell, J. D. (1970). Empirical Research: A Key to the Kingdom for the Business Law Instructor. Am. Bus. LJ, 8, 287.

[11] Galas, D. J., Patrinos, A., \& DeLisi, C. (2017). Notes from a Revolution Lessons from the Human Genome Project. Issues in Science and Technology, 33(3), 57-62.

[12] Giaglis, G. M. (2008). Directions and trends in knowledge management research: Results from an empirical analysis of European projects. In

${ }^{47}$ Kothari, C. R. (2004). Research methodology: Methods and techniques. New Age International.

Also see: Singh, B. B., \& Guled, C. N. (2016). Conceptuality Of Research Methodology: Some Introductory Remarks.

Everyman's Science, 156.

Also see: Janota, A., Lobotková, Z., Slivka, M., \& Halgaš, J.

(2010). The role of hypothesis in scientific research.

Logistyka, (6).

Also see: Bist, R. B. (2014). Research Procedure: An

Introduction. Journal of NELTA Surkhet, 4, 34-40.

48 Bhome, S. M., Prajapati, N., Deshmukh-Ghate, D., \& Ghosh, A. (2015). Research Methodology (Tools and Analysis), Himalaya Publishing House. 
Knowledge Management: Concepts, Methodologies, Tools, and Applications (pp. 1438-1449). IGI Global.

[13] Guil, J. M., Masiá, A. P., Paniego, A. R., \& Menayo, J. T. (1998). Energetics of $\mathrm{H} 2$ and $\mathrm{O} 2$ adsorption on $\mathrm{Ir} / \gamma-\mathrm{Al} 2 \mathrm{O} 3$ and $\mathrm{Ir} / \mathrm{SiO} 2$ catalysts. Dependence on support and on metal particle size. Thermochimica acta, 312(1-2), 115124.

[14] Guillemin, M., \& Gillam, L. (2004). Ethics, reflexivity, and "ethically important moments" in research. Qualitative inquiry, 10(2), 261-280.

[15] Hudson Maxim (February 3, 1853 - May 6, 1927), was a U.S. inventor and chemist who invented a variety of explosives, including smokeless gunpowder, Thomas Edison referred to him as "the most versatile man in America".

[16] Ismail, A. M., Mujani, W. K., Hussain, W. M. H. W., \& Ya'akub, N. I. (2012). The missing of moral entity in modern civilization: values and social aspects. Advances in Natural and Applied Sciences, 6(6), 985-995.

[17] Iyama, S. (2004). The USPTO's proposal of a biological research tool patent pool doesn't hold water. Stan. L. Rev., 57, 1223.

[18] Janota, A., Lobotková, Z., Slivka, M., \& Halgaš, J. (2010). The role of hypothesis in scientific research. Logistyka, (6).

[19] Khan, A. A. (2012). Islamic Society: Ethics, Human Rights, Adornments \& Recreation. Defence Journal, 15(10), B1.

[20] Kiulah, B. M. (2013). A Discussion On The Ethical Issues Encountered In The Process Of Carrying Out Research.

[21] Kothari, C. R. (2004). Research methodology: Methods and techniques. New Age International.

[22] Kruk, J. (2013). Good scientific practice and ethical principles in scientific research and higher education. Central European Journal of Sport Sciences and Medicine, 1(1), 25-29.

[23] Masic, I. (2012). Plagiarism in scientific publishing. Acta Informatica Medica, 20(4), 208.

[24] Master, Z. (2011). The responsible conduct of bioethics research. Accountability in Research, 18(2), 102-119.
[25] McKellar, K., \& Toth, N. (2016). Ethical Considerations in Face-to-Face and Internet-Mediated Research with Teenage Populations. In Perspectives on HCI Research with Teenagers (pp. 29-59). Springer, Cham.

[26] Mujtaba, B. G. (1997, March). Corporate Ethics Training Programs. In Developments in Business Simulation and Experiential Learning: Proceedings of the Annual ABSEL conference (Vol. 24).

[27] Prabhat, P. and Meenu, M. P. (2015). Research Methodology: Tools and Techniques, 1st ed, Bridge Center- Romania.

[28] Rexford, N., \& Cunnington, P. Methodology/Dress History/Historiography.

[29] Shamoo, A. E., \& Dunigani, C. D. (2000). Ethics in Research2 (44535B). Proceedings of the Society for Experimental Biology and Medicine, 224(4), 205-210.

[30] Singh, B. B., \& Guled, C. N. (2016). Conceptuality Of Research Methodology: Some Introductory Remarks. Everyman's Science, 156.

[31] Tyagi, N., Varshney, R. G., \& Chandramouli, A. B. (2013). A novel approach to study the research methodology. International Journal of Management, IT and Engineering, 3(11), 248.

\section{AUTHORS}

First Author - Md. Sirajul Islam ibn Sultan Ahmad, PhD candidate, Department of Qur'an \& Sunnah Studies, Kulliyyah of Islamic Revealed Knowledge and Human Sciences, International Islamic University Malaysia, 53100 Jalan Gombak, Kuala Lumpur, Malaysia. E-mail: sirajulislam1981@yahoo.com Second Author - Assistant Prof. Dr. Sofiah Bt. Samsudin, Department of Qur'an \& Sunnah Studies, Kulliyyah of Islamic Revealed Knowledge and Human Science, International Islamic University Malaysia, 53100 Jalan Gombak, Selangor, Kuala Lumpur, Malaysia. E-mail: Sofiahs@iium.edu.my 